\title{
El tratamiento para la fibromialgia con ejercicio físico en agua caliente reduce el impacto de la enfermedad en la salud física y mental de mujeres afectadas
}

Pablo Tomas-Carus ${ }^{a}$, Narcís Gusi ${ }^{b}$, Alejo Leal ${ }^{c}$, Yolanda García ${ }^{b}$ y Alfredo Ortega-Alonso ${ }^{d}$

aDepartamento de Salud y de Bienestar. Universidad de Évora. Évora. Portugal.

bFacultad de Ciencias del Deporte. Universidad de Extremadura. Cáceres. España.

'Complejo Hospitalario de Cáceres. Hospital Virgen de la Montaña. Cáceres. España.

¿Departamento de Ciencias de la Salud. Universidad de Jyväskylä. Jyväskylä. Finlandia.

Introducción: Los pacientes con fibromialgia (FM) muestran dolor, rigidez muscular, condición física reducida y fatiga que limitan sus actividades de la vida diaria. El propósito de este estudio fue evaluar los efectos de la adición al tratamiento médico clásico de 12 semanas de ejercicio físico en agua caliente en el impacto de la FM en la salud física y mental de mujeres afectadas.

Pacientes, material y métodos: Treinta y cuatro pacientes no entrenadas físicamente se distribuyeron aleatoriamente en 2 grupos: un grupo experimental $(n=17)$, que realizó 3 sesiones semanales de $60 \mathrm{~min}$ de ejercicio físico en agua caliente, y un grupo de control $(\mathrm{n}=17)$, que no recibió dicho tratamiento adicional. El impacto de la FM en la salud física y mental de las pacientes fue evaluado mediante el Cuestionario del Impacto de la Fibromialgia (Fibromyalgia Impact Questionnaire [FIQ]).

Resultados: A las 12 semanas de ejercicio físico se observaron mejoras significativas en el grupo

experimental respecto al grupo de control, en la función física $(35 \% ; p=0,016)$, sentirse bien $(34 \% ; p=0,003)$, la capacidad de trabajo $(14 \% ; p=0,046)$, el dolor $(26 \%$; $\mathrm{p}=0,030)$, la rigidez $(33 \% ; \mathrm{p}=0,038)$, la ansiedad $(36 \%$; $\mathrm{p}=0,044)$, la depresión $(26 \% ; \mathrm{p}=0,046)$ y en la escala total del FIQ $(27 \% ; p=0,004)$.

Conclusiones: La adición del programa de ejercicio físico acuático al tratamiento médico usual redujo el impacto de la FM en la salud física y mental de las pacientes. Sin embargo, el efecto placebo podría haber contribuido parcialmente en estas mejoras.

Palabras clave: Fibromialgia. Ejercicio en agua caliente. Salud física y mental.

Correspondencia: Prof. Dr. P. Tomás Carús.

Pavilhão Gimnosdesportivo da Universidade de Évora.

Prolongamiento da Rua de Reguengos de Monsaraz, 14. 7000-727 Évora. Portugal.

Correo electrónico: ptcarus@unex.es

Manuscrito recibido el 18-4-2006 y aceptado el 30-11-2006
The fibromyalgia treatment with physical exercise in warm water reduces the impact of the disease on female patients' physical and mental health

Introduction: Fibromyalgia (FM) patients present pain, muscle stiffness, reduced physical condition and fatigue that limit their daily life activities. The purpose of this study was to evaluate the effects of the addition of 12 weeks of physical exercise in warm water to usual medical care on the impact of FM on physical and mental health in female patients.

Patients, materials and methods: Thirty four physically untrained females with FM were randomly assigned into two groups: an experimental group ( $\mathrm{n}=17)$, to perform 3 weekly sessions for 60 minutes of physical exercise in warm water; and control group ( $n=17)$, who did not receive the additional treatment. The impact of the FM on patients' physical and mental health was assessed using the Fibromyalgia Impact Questionnaire (FIQ).

Results: After 12 weeks of physical exercise, the experimental group showed improvements compared to the control group in physical function $(35 \%, P=0.016)$, feel good (34\%, $P=0.003)$, job ability $(14 \%, P=0.046)$, pain $(26 \%, P=0.030)$, stiffness $(33 \%, P=0.038)$, anxiety (36\%, $P=0.044)$, depression $(26 \%, P=0.046)$, and FIQ total scores $(27 \%, P=0.004)$.

Conclusions: The addition of the aquatic physical exercise programme to usual care was effective to decrease the impact of the disease on physical and mental health. However, the placebo effect could have contributed to this effectiveness.

Key words: Fibromyalgia. Warm-water exercise. Physical and mental health.

\section{Introducción}

La fibromialgia (FM) es una enfermedad crónica caracterizada por dolor generalizado, rigidez muscular, con- 